\title{
PENGARUH METODE DEMONSTRASI DAN METODE EKSPOSITORI TERHADAP HASIL BELAJAR MENGOPERASIKAN SISTEM PENGENDALI ELEKTROMAGNETIK (MSPEM) DI SMK NEGERI 1 LUBUK PAKAM
}

\author{
Abdul Hakim Butar- Butar dan Annita Seliana Siregar \\ Dosen Pendidikan Teknik Elektro, Fakultas Teknik, Universitas Negeri Medan \\ Alumni Pendidikan Teknik Elektro, Fakultas Teknik, Universitas Negeri Medan \\ Jl. Willem Iskandar Pasar V - Medan 20221 \\ abdulhakimbutar2@yahoo.com
}

\begin{abstract}
ABSTRAK
Penelitian ini bertujuan untuk mengetahui perbandingan hasil belajar mengoperasikan system pengendali elektromagnetik (MASPEM) pada siswa yang diajar dengan Model Pembelajaran demonstrasi dan siswa yang diajar dengan Model Pembelajaran ekspositori di smk n 1 lubuk pakam tahun pengajaran 2014-2015. Metode yang digunakan dalam penelitian ini adalah eksperimental, yang mana dalam pelaksanaannya sengaja diberikan perlakuan (treatment) kepada kelompok eksperimen. Populasi dalam penelitian ini adalaha seluruh siswsa kelas XI program keahlian teknik instalasi tenaga listrik ITITL), berjumlah 2 kelas, kelas eksperimen berjumlah 35 orang dan control berjumlah 33 orang, dan total subjek yang akan diteliti sebanyak 68 siswa. Berdasarkan hasil analisis data diperoleh perbedaan hasil belajar MASPEM pada kompetensi dasar Memahami prinsip kerja pengoperasian system kendali elektromagnetik. Nilai rata-rata hasil belajar siswa pada Kelas eksperimen 78,857 dan Kelas kontrol sebesar 69.09. Untuk menguji normalitas data digunakan uji liliefors pada taraf signifikasni $95 \%$ dan taraf nyata $(\alpha)$ sebesar 0,05. Uji normalitas pada Kelas eksperimen diperoleh Lhitung sebesar 0,045 dan Ltabel sebesar 0,149 karena Lhitung < Ltabel atau 0,045 < 0,149 maka data instrument pada kelas eksperimen pada kategori normal, dan Uji normalitas pada Kelas kontrol diperoleh Lhitung sebesar 0,011 dan Ltabel sebesar 0,154 maka data instrument pada kelas kontrol pada kategori normal. Uji Homogenitas F sebesar 1,115 dan Ft sebesar 1,837,karena Fhitung < Ftabel maka seluruh varian homogen. Dengan pengujian hipotesis menggunkan uji-t dengan taraf signifikansi $5 \%$ menunjukan bahwa terdapat perbandingan hasil pembelajaran pada siswa yang diajar metode demonstrasi dilihat dari thitung 2.051 yang lebih besar dari ttabel 1,671.
\end{abstract}

\section{Kata Kunci : Metode Demontrasi, Metode Ekspositori, Sistem Pengendali Elektromagnetik}

\section{PENDAHULUAN}

Seiring dengan perkembangan ilmu pengetahuan dan teknologi yang semakin pesat, menuntut manusia untuk terus mengembangkan wawasan dan kemampuan di berbagai bidang. Pendidikan sangat penting bagi manusia dan tidak dapat dipisahkan dari kehidupan manusia. Oleh karena itu pendidikan harus dapat dilaksanakan dengan sebaik mungkin sehingga akan memperoleh hasil yang di harapkan.

Sekolah menengah kejuruan merupakan salah satu lembaga pendidikan yang bertujuan untuk mempersiapkan lulusan menjadi tenaga kerja yang mempunyai pengetahuan dan keterampilan yang menengahsesuai dengan bidangnya. Hal ini sesuai dengan tujuan SMK dalam GBPP, yaitu : (1) Menyiapkan siswa untuk memasuki lapangan kerja serta mengembangkan sikap profesional, (2) Menyiapkan siswa agar mampu memilih karir, mampu berkompetensi dan mampu mengembangkan diri, (3) Menyiapkan tenaga kerja tingkat menengah pada saat ini maupun pada saat mendatang, (4) Menyiapkan tamatan agar mampu menjadi warga negara yang produktif, adaptif dan kreatif. 
Sekolah menengah kejuruan di SMK Negeri 1 Lubuk Pakam adalah salah satu sekolah dalam bidang keteknikan. Dari survey yang di lakukan di lapangan dengan mendapat pendapat guru bidang studi bahwasanya hasil belajar siswa kelas II TITLa untuk kompetensi Mengoperasikan Sistem Pengendali Elektromagnetik dianggap rendah dengannilai rata-ratanya 6,9 (pada lampiran), sedangkan untuk standard

competensi yang di tetapkan oleh depdiknas (pusat kurikulum, balitbang, 2002 ) adalah di atas 7,0.

Hasil wawancara dengan Bapak Drs.

Ghazali Siregar yang merupakan guru bidang studi Mengoperasikan Sistem Pengendali Elektromagnetik mengatakan bahwasanya sampai saat ini pembelajaran yang dilaksanakan khususnya untuk kompetensi Mengoperasikan Sistem Pengendali Elektro magnetik masih menggunakan metode ekspositori. Dalam pembelajaran ekspositori guru merupakan sumber data yang penting sekaligus komponen penting dalam proses pembelajaran. ekspositori guru cenderung menggunakan kontrol proses pembelajaran dengan aktif, sementara peserta didik menerima dan mengikuti apa yang diprogramkan dan disajikan oleh guru. Pada kondisi seperti ini siswa akan merasa bosan dalam mengikuti proses pembelajaran yang pada akhirnya berkurang terhadap hasil belajar siswa. Padahal guru merupakan salah satu kunci dalam keberhasilan peningkatan hasil belajar siswa.

Berdasarkan hasil observasi dan wawancara dengan guru bidang studi di SMK Negeri 1 Lubuk Pakam khususnya pada kompetensi Mengoperasikan Sistem Pengendali Elektromagnetik yang di ajarkan oleh guru, merupakan mata diklat yang di ajarkan pada kelas XI Teknik Listrik (TITL). Selama ini guru hanya menggunakan metode pembelajaran ekspositori (Ceramah) sehingga siswa cenderung pasif dalam mengikuti proses pembelajaran.Tahapan pembelajaran ekspositori adalah sebagai berikut; (1) pada tahap pendahuluan guru menyampaikan pokok-pokok materi yang akan dibahas dan tujuan pembelajaran yang ingin dicapai, peserta didik mendengarkan dan mencatat hal-hal yang dianggap penting, (2) pada tahap penyajian atas materi guru yang menyampaikan materi pembelajaran dengan ceramah dan tanya jawab, kemudian dilanjutkan dengan demonstrasi untuk memperjelas materi yang disajikan dan diakhiri dengan penyampaian latihan, (4) pada tahap penutup melaksanakan evaluasi berupa tes dan kegiatan tindak lanjut seperti penguasaan dalam rangka perbaikan dan pemantapan atau pendalaman materi. Kondisi seperti itu dapat dilihat dari hasil belajar siswa semester genap pada TP. 2014/2015 dari 30 siswa hanya $40.3 \%$ atau 21siswayang mampu mencapai kriteria ketuntasan minimal yaitu 70 .

Kemudian komponen yang mempengaruhi kualitas pendidikan di antaranya adalah guru, siswa, materi belajar, sumber belajar, media, sarana dan prasarana serta proses pembelajaran.Faktor lain yang mempengaruhi hasil belajar di sekolah juga dapat dipengaruhi oleh latar belakang keluarga, ekonomi, sosial dan budaya dari setiap diri siswa.Faktor-faktor tersebut dapat berhubungan dengan kepercayaan diri siswa dilingkungan sekolah, baik dalam menjalin hubungan dengan teman sebaya, maupun dengan guru di sekolah. Selain itu faktor minat juga memberikan kontribusi dalam mendorong siswa untuk aktif dalam kegiatan pembelajaran. Belum lagi masalah ketersedian sarana dan prasarana yang memadai yang dapat membantu siswa dalam mengembangkan potensi diri sehingga minat untuk belajar akan lebih terbangun, dengan artian siswa dapat menemukan apa yang dibutuhkan untuk mendukung proses pembelajaran di sekolah.

Dari sekian banyak masalah tersebut, salah satu masalah penting yang dihadapi pendidikan kita adalah masalah minimnya keterlibatan siswa di dalam proses pembelajaran. Dalam proses pembelajaran, siswa kurang didorong untuk mengembangkan kemampuan berpikir.

Dengan keadaan diatas, maka perlu diadakan inovasi metode belajar yang diharapkan lebih efektif dan efisien. Oleh karena itu guru sebagai sentral dalam pengembangan pendidikan, maka guru harus merencanakan, mengorganisasikan, me- 
ngelola proses belajar sedemikian rupa sehingga bahan ajar yang diberikan dapat diserap dan dimiliki siswa dengan baik. Guru harus dapat mendesain pengajaran dengan baik dan dapat menerapkan metode pembelajaran yang sesuai. Salah satu alternatif yang dapat digunakan untuk mengatasi masalah tersebut adalah menggunakan metode pembelajaran demonstrasi dalam proses pembelajaran.

Dari sekian banyak masalah tersebut, salah satu masalah penting yang dihadapi pendidikan kita adalah masalah minimnya keterlibatan siswa di dalamproses pembelajaran. Dalam proses pembelajaran, siswa kurang didorong untuk mengembangkan kemampuan berpikir. Pembelajaran menggunakan alat peraga berarti mengoptimalkan fungsi seluruh panca indra siswa untuk meningkatkan efektivitas siswa belajar dengan cara mendengar, melihat, meraba, dan menggunakan pikirannya secara logis dan realistis. Metode pembelajaran demonstrasi (Peraga) atau bermain peran adalah metode yang cocok untuk membantu siswa dalam menguasai materi pelajaran. Metode ini menggunakan alat peraga dan memaksimalkan semua fungsi kerja indra dari siswa dalam proses pemahaman materi. Seluruh siswa akan dapat berpartisipasi dan mempunyai kesempatan untuk menunjukkan kemampuannya dalam bekerja sama dengan siswa yang lain hingga berhasil.

Metode Demonstrasi (Alat Peraga) ini sangat banyak melibatkan siswa untuk lebih kreatif dan beraktivitas dalam pembelajaran, sehingga akan menciptakan suasana yang menyenangkan dan meningkatnya antusiasme siswa dalam mengikuti pelajaran yang pada akhirnya dapat meningkatan hasil belajar siswa.

Dari sekian banyak masalah tersebut, salah satu masalah penting yang dihadapi pendidikan kita adalah masalah minimnya keterlibatan siswa di dalam proses pembelajaran. Dalam proses pembelajaran, siswa kurang didorong untuk mengembangkan kemampuan berpikir.Proses pembelajaran yang masih banyak terjadi cenderung hanya diarahkan kepada kemampuan siswa untuk menghafal informasi, siswa dipaksa untuk mengingat dan menimbun berbagai informasi tanpa dituntut untuk memahami dan menghubungkannya dengan kehidupan sehari-hari. Akibatnya, ketika siswa lulus dari sekolah, mereka pintar secara teoritis, tetapi mereka miskin aplikasi.

Belajar adalah suatu proses usaha yang dilakukan seseorang untuk memperoleh suatu perubahan tingkah laku yang baru secara keseluruhan, sebagai hasil pengalamannya sendiri dalam interaksi dengan lingkungannya (Slameto, 2003). Menurut Slameto perubahan yang terjadi dalam diri seseorang banyak sekali baik sifat maupun jenisnya karena itu sudah tentu tidak setiap perubahan dalam diri seseorang merupakan perubahan dalam arti belajar.Kalau tangan seorang anak menjadi bengkok karena patah tertabrak mobil, perubahan itu tidak dapat digolongkan kedalam perubahan dalam arti belajar. Demikian pula perubahan tingkah laku seseorang dalam keadaan mabuk, perubahan yang terjadi dalam aspek-aspek kematangan, pertumbuhan, dan perkembangan tidak termasuk perubahan dalam arti belajar.

Menurut Purba (2004), belajar adalah sebagai suatu proses mental yang terjadi dalam benak seseorang yang melibatkan kegiatan (proses) berpikir dan terjadi melalui pengalaman-pengalaman yang didapat seseorang melalui reaksi-reaksi terhadap lingkungan dimana dia berada sehingga terjadi perubahan perilaku di dalam diri seseorang/ individu yang belajar.

Dengan demikian bukti bahwa seseorang telah melakukan kegiatan belajar ialah adanya perubahan tingkah laku pada orang tersebut yang sebelumnya tidak ada atau tingkah lakunya masih kurang. Perubahan itu dapat berupa pengembangan pengetahuan, keterampilan dan sikap yang nantinya diharapkan mampu memecahkan masalah yang dihadapinya. Kegiatan dan usaha untuk mencapai perubahan tingkah laku tersebut adalah proses belajar, sedangkan perubahan tingkah laku adalah hasil belajar.

Hasil belajar menunjukkan tingkat kemampuan siswa dalam mengikuti sebuah proses pembelajaran. Winkel (1996) 
menggolongkan kemampuan sebagai hasil belajar menjadi kemampuan kognitif, kemampuan sensori-motorik dan kemampuan dinamik afektif. Semua perubahan di bidang ini merupakan suatu hasil belajar dan mengakibatkan manusia berubah dalam sikap dan tingkah lakunya.

Ada dua faktor yang mempengaruhi hasil belajar, yaitu (a) Faktor yang datang dari dalam diri sendiri (internal), diantaranya adalah keadaan fisik secara umum, dan fisikologi meliputi variabel kognitif yang termasuk didalamnya adalah kemampuan khusus (bakat) dan kemampuan umum (kecerdasan), sedangkan variabel non kognitif yang termasuk didalamnya adalah minat, motivasi dan variabel kepribadian, dan (b) Faktor yang datang dari luar (eksternal), diantaranya adalah aspek fisik seperti kondisi tempat belajar, sarana dan prasarana belajar, materi pelajaran, dan kondisi lingkungan belajar, sedangkan aspek sosial meliputi pengaruh budaya dan lingkungan sosial.

Mengoperasikan Sistem Pengendali Elektromagnetik (MSPEM)merupakan salah satu sub kompetensi dalam program produktif yang harus dikuasai oleh siswa SMK program keahlian teknik pemamfaatan energi listrik. Mengoperasikan Sistem Pengendali Elektromagnetik (MSPEM) memiliki 64 jam pelajaran yang diberikan pada semester satu tingkat satu.

Dari penjelasan diatas maka yang dimaksud hasil belajar Mengoperasikan Sistem Pengendali Elektromagnetik (MSPEM) dalam penelitian ini yaitu unjuk kerja siswa dalam aspek kognitif yang dapat ditunjukkan melalui tes hasil belajar yang disusun sesuai materi pembelajaran yang diajarkan.

Menurut Romiszowski (1984), pembelajaran ekspositori berlangsung melalui beberapa tahap sebagai berikut. Pertama, penyajian informasi. Penyajian informasi dapat dilakukan dengan ceramah, latihan. Kedua,tes pengguasaan dan penyajian ulang bila dipandang perlu. Ketiga, memberikan kesempatan penerapan dalam bentuk contoh dan soal. Keempat, memberikan kesempatan penerapan informasi barudalam situasi dan masalah sebenarnya.
Metode pembelajaran ekspositori menempatkan guru sebagai pusat pengajaran, karena guru lebih aktif dalam memberikan informasi sebagai pengelola dan pengendali seluruh kegiatan pembelajaran. Pada umumnya guru menyampaiakan meteri pelajaran melalui ceramah dengan harapan siswa dapat memahaminya dan memberikan respon sesuai dengan materi yang diajarkan.

Meskipun dalam pembelajaran ekspositori yang digunakan selain ceramah dan dilengkapi atau didukung dengan penggunaan media, penekananya tetap dalam proses pengetahuan. Pembelajaran ekspositori memberikan dua keuntungan utama, yaitu dari segi waktu dan pengawasan. Melalui pembelajaran ekspositori materi dapat cepat diterima siswa.

Metode pembelajaran ekspositori adalah metode pembelajaran yang menekankan kepada proses penyampaian materi secara verbal dari seorang guru kepada sekelompok siswa dengan maksud agar siswa dapat menguasai matrei dan pelajaran secara optimal. Roy killen menamakan metode ekspositori ini dengan istilah metode pembelajaran langsung (dirrect intruction), karena dalam metode ini materi pelajaran disampaikan langsung oleh guru. Siswa tidak dituntut untuk menemukan materi itu. Metode ekspositori sama seperti metode ceramah. Kedua metode ini menjadikan guru sebagai pemberi informasi (bahan pelajaran).

Dominasi guru dalam kegiatan belajar-mengajar metode ceramah lebih terpusat pada guru dari pada metode ekspositori. Pada metode ekspositori siswa lebih aktif dari pada metode ceramah. Siswa mengerjakan latihan soal sendiri, mungkin juga saling bertanya dan mengerjakan bersama dengan siswa lain, atau disuruh membuatnya dipapan tulis. Metode ekspositori adalah cara penyamppaian pelajaran dari seorang guru kepada siswa didalam kelas dengan cara berbicara diawal pelajaran, menerangkan materi dan contoh soal disertai tanya jawab. Gurur dapat memriksa pekerjaan siswa secara individual, menerangkan lagi kepada siswa apabila dirasakan banyak kepada siswa yang belum paham mengenai materi. Kegiatan siswa 
tidak hanya mendengar dan mencatat, tetapi siswa juga menyeleseaikan latihan soal dan bertanya bila belum mengerti.

Berdasarkan uraian diatas, dapat disimpulkan bahwa metode pembelajaran ekspositori adalah suatu metode pembelajaran yang cara penyampaian materinya secara langsung oleh guru kepada siswa dengan tujuan siswa dapat menguasai materi secara optimal. Materi pelajaran yang disampaikan oleh guru dalam metode pembelajaran ekspositori biasanya materi pelajaran yang sudah jadi, seperti data atau fakta, konsep-konsep tertentu yang harus dihafal sehingga tidak menuntut siswa untuk bertutur ulang.

Beberapa penelitian yang relevan dengan penelitian ini adalah penelitian yang dilakukan oleh Rostiyah NK (2001) mengatakan bahwa dengan demosntrasi proses penerimaan siswa terhadap pelajaran akan lebih baik dan berkesan secara mendalam, sehingga membentuk pengertian dengan baik dan sempurna.

Menurut Estiningsih (1994) alat peraga merupakan media pembelajaran yang mengandung atau membawakan ciri-ciri konsep yang dipelajari. Alat peraga merupakan salah satu komponen penentu efektivitas belajar. Alat peraga mengubah materi ajar yang abstrak menjadi kongkrit dan realistik. Penyediaan perangkat alat peraga merupakan bagian dari pemenuhan kebutuhan siswa belajar, sesuai dengan tipe siswa belajar.

Alat peraga disusun berdasarkan prinsip bahwa pengetahuan yang ada pada setiap manusia itu diterima atau ditangkap melalui panca indera. Semakin banyak indera yang digunakan untuk menerima sesuatu maka semakin banyak dan semakin jelas pula pengertian / pengetahuan yang diperoleh. Dengan perkataan lain, alat peraga ini dimaksudkan untuk mengerahkan indera sebanyak mungkin kepada suatu objek sehingga mempermudah persepsi.

Ada beberapa hasil penelitian yang relevan dengan penelitian yang dilaksanakan. Hasil penelitian ini dapat digunakan untuk pengembangan terhadap penelitian yang diilaksanakan.
Penelitian Naima (2009) tentang pengaruh penggunaan media konkrit dan gambar serta motivasi terhadap hasil belajar siswa kelas V Madrasah Itbidiyah di Kota Pali. Penelitian dilakukan dengan membagi siswa menjadi kelompok, yakni kelompok eksperimen dan kelompok kontrol. Kelompok eksperimen menggunakan media konkrit dan gambar pada kegiatan belarjarnya, sedangkan kelompok kontrol hanya menggunakan metode ceramah pada kegiatan belajarnya. Hasil penelitian menunjukan bahwa ada pengaruh positif terhadap siswa yang menggunakan media konkrit dan gambar terhadap motivasi dan hasil belajar bila dibandingkan dengan kelompok yang tanpa menggunakan media konkrit.

\section{KAJIAN TEORITIS}

Belajar adalah suatu proses usaha yang dilakukan seseorang untuk memperoleh suatu perubahan tingkah laku yang baru secara keseluruhan, sebagai hasil pengalamannya sendiri dalam interaksi dengan lingkungannya (Slameto, 2003), Purba (2004). Hasil belajar menunjukkan tingkat kemampuan siswa dalam mengikuti sebuah proses pembelajaran. Winkel (1996) menggolongkan kemampuan sebagai hasil belajar menjadi kemampuan kognitif, kemampuan sensori-motorik dan kemampuan dinamik afektif. Semua perubahan di bidang ini merupakan suatu hasil belajar dan mengakibatkan manusia berubah dalam sikap dan tingkah lakunya.

Ada dua faktor yang mempengaruhi hasil belajar, yaitu : (a) Faktor yang datang dari dalam diri sendiri (internal), diantaranya adalah keadaan fisik secara umum, dan fisikologi meliputi variabel kognitif yang termasuk didalamnya adalah kemampuan khusus (bakat) dan kemampuan umum (kecerdasan), sedangkan variabel non kognitif yang termasuk didalamnya adalah minat, motivasi dan variabel kepribadian, dan (b) Faktor yang datang dari luar (eksternal), diantaranya adalah aspek fisik seperti kondisi tempat belajar, sarana dan prasarana belajar, materi pelajaran, dan kondisi lingkungan 
belajar, sedangkan aspek sosial meliputi pengaruh budaya dan lingkungan sosial.

Hasil belajar dapat diketahui melalui penilaian dengan cara mengukur dan mengevaluasi tingkat keberhasilan belajar tersebut melalui tes. Penilaian hasil belajar ini bertujuan untuk mengetahui kemampuan belajar siswa dalam hal penguasaan materi atau untuk mengetahui status siswa dan kedudukannya baik secara individu maupun secara kelompok, yaitu (a) Ranah kognitif : berhubungan dengan kemampuan berpikir, (b) Ranah afektif : ranah ini menyangkut aspek sikap yang paling utama dalam pembentukan kepribadian seseorang, dan (c) Ranah psikomotorik : ranah ini berhubungan dengan kemampuan motorik atau gerak yang terkoordinasi yang memungkinkan seseorang menjadi terampil dan aktif.

Mengoperasikan Sistem Pengendali Elektromagnetik (MSPEM) merupakan salah satu sub kompetensi dalam program produktif yang harus dikuasai oleh siswa SMK program keahlian teknik pemamfaatan energi listrik. Mengoperasikan Sistem Pengendali Elektromagnetik (MSPEM) memiliki 64 jam pelajaran yang diberikan pada semester satu tingkat satu.

Penerapan metode pembelajaran demonstrasi dapat meningkatkan hasil belajar siswa pada kompetensi Mengoperasikan Sistem Pengendali Elektromagnteik. Metode demonstrasi ini adalah metode pembelajaran yang cara menyampaikan metode pembelajaran dengan memperagakan atau menampilkan alat dan bahanyang sesungguhnya yang dapat diperagakan langsung oleh siswa dengan cara mengoperasikan alat yang digunakan dalam kegiatan praktek dengan aturan dan urutan kegiatan, baik secara langsung maupun melalui penggunaan media pembelajaran yang relevan dengan pokok bahasan yang disajikan oleh guru.

Metode demonstrasi adalah metode mengajar dengan cara memperagakan langsung akan barang, kejadian, aturan, dan urutan melakukan suatu kegiatan, baik secara langsung maupun melalui penggunaan media pembelajaran yang relevan dengan pokok bahasan atau materi yang sedang disajikan. (Muhinnin Syah, 2003). Metode demonstrasi adalah metode yang digunakan untuk memperlihatkan sesuatu proses atau cara kerja suatu benda yang berkenaan dengan bahan pelajaran. (Syaiful Bahri Djamrah 2000). Metode demonstrasi ialah metode mengajar dengan menggunakan alat peragaanuntuk memperjelas suatu pengertian atau untuk memperlihatkan bagaimana berjalanya suatu proses pembentukan tertentu pada siswa.

Martinis Yamin $(2008 ; 75)$ mengatakan bahwa metode demonstrasi dapat digunakan dengan syarat memliki keahlian untuk mendemonstrasikan pengguanaan alat atau melaksanakan kegiatan yang sesungguhnya. Metode demonstrasi merupakan salah satu metode yang dapat meningkatkan hasil belajar siswa. Metode demonstrasi merupakan salah satu tipe dari pembelajarn aktif.

Dalam metode demonstrasi guru harus mampu menyusun rumusan dan tujuan agar dapat memberikan motivasi yang kuat terhadap siswa agar kegiatan belajar siswa dapat meningkat dan kemauan belajar siswa dapat tercapai. Metode pembelajaran demonstrasi ini mampu menjamin tercapainya tujuan yang telah anda rumuskan dalam metode pembelajaran dengan kompetensi Mengoperasikan Sistem Pengendali Elektromagnetik yang memberikan siswa kesempatan dalam melaksanakan kegiatan dalam proses pembelajaran dengan meneliti alat dan bahan yang akan dpergunakan siswa dalam melaksanakan peraktek.

Dalam pembelajaran demonstrasi guru memberikan garis-garis besar yang akan dilakukan oleh siswa dalam melaksanakan kegiatan dan memberikan waktu yang cukup agar siswa lebih tenang dalam melaksanakan kegiatan yang berlangsung. Selama siswa melakukan kegiatan guru memberikan siswa kesempatan untuk mengamati dengan baik dan bertanya agar siswa mampu melaksanakan proses pembelajaran dengan baik serta mengadakan evaluasi apakah demonstrasi yang dilakukan itu berhasil.

Metode pembelajaran ekspositori menempatkan guru sebagai pusat pengajaran, karena guru lebih aktif dalam memberikan informasi sebagai pengelola dan pengendali 
seluruh kegiatan pembelajaran. Pada umumnya guru menyampaiakan meteri pelajaran melalui ceramah dengan harapan siswa dapat memahaminya dan memberikan respon sesuai dengan materi yang diajarkan.

Meskipun dalam pembelajaran ekspositori yang digunakan selain ceramah dan dilengkapi atau didukung dengan penggunaan media, penekananya tetap dalam proses pengetahuan. Pembelajaran ekspositori memberikan dua keuntungan utama, yaitu dari segi waktu dan pengawasan. Melalui pembelajaran ekspositori materi dapat cepat diterima siswa.

Metode pembelajaran ekspositori adalah metode pembelajaran yang menekankan kepada proses penyampaian materi secara verbal dari seorang guru kepada sekelompok siswa dengan maksud agar siswa dapat menguasai matrei dan pelajaran secara optimal. Roy killen menamakan metode ekspositori ini dengan istilah metode pembelajaran langsung (dirrect intruction), karena dalam metode ini materi pelajaran disampaikan langsung oleh guru. Siswa tidak dituntut untuk menemukan materi itu. Metode ekspositori sama seperti metode ceramah. Kedua metode ini menjadikan guru sebagai pemberi informasi (bahan pelajaran).

Dominasi guru dalam kegiatan belajar-mengajar metode ceramah lebih terpusat pada guru dari pada metode ekspositori. Pada metode ekspositori siswa lebih aktif dari pada metode ceramah. Siswa mengerjakan latihan soal sendiri, mungkin juga saling bertanya dan mengerjakan bersama dengan siswa lain, atau disuruh membuatnya dipapan tulis. Metode ekspositori adalah cara penyamppaian pelajaran dari seorang guru kepada siswa didalam kelas dengan cara berbicara diawal pelajaran, menerangkan materi dan contoh soal disertai tanya jawab. Gurur dapat memriksa pekerjaan siswa secara individual, menerangkan lagi kepada siswa apabila dirasakan banyak kepada siswa yang belum paham mengenai materi. Kegiatan siswa tidak hanya mendengar dan mencatat, tetapi siswa juga menyeleseaikan latihan soal dan bertanya bila belum mengerti.
Berdasarkan uraian diatas, dapat disimpulkan bahwa metode pembelajaran ekspositori adalah suatu metode pembelajaran yang cara penyampaian materinya secara langsung oleh guru kepada siswa dengan tujuan siswa dapat menguasai materi secara optimal. Materi pelajaran yang disampaikan oleh guru dalam metode pembelajaran ekspositori biasanya materi pelajaran yang sudah jadi, seperti data atau fakta, konsep-konsep tertentu yang harus dihafal sehingga tidak menuntut siswa untuk bertutur ulang.

Penelitian yang relevan dengan penelitian ini adalah penelitian yang dilakukan oleh Rostiyah NK (2001) mengatakan bahwa dengan demosntrasi proses penerimaan siswa terhadap pelajaran akan lebih baik dan berkesan secara mendalam, sehingga membentuk pengertian dengan baik dan sempurna.

Menurut Estiningsih (1994) alat peraga merupakan media pembelajaran yang mengandung atau membawakan ciri-ciri konsep yang dipelajari. Alat peraga merupakan salah satu komponen penentu efektivitas belajar. Alat peraga mengubah materi ajar yang abstrak menjadi kongkrit dan realistik. Penyediaan perangkat alat peraga merupakan bagian dari pemenuhan kebutuhan siswa belajar, sesuai dengan tipe siswa belajar.

Alat peraga disusun berdasarkan prinsip bahwa pengetahuan yang ada pada setiap manusia itu diterima atau ditangkap melalui panca indera. Semakin banyak indera yang digunakan untuk menerima sesuatu maka semakin banyak dan semakin jelas pula pengertian / pengetahuan yang diperoleh. Dengan perkataan lain, alat peraga ini dimaksudkan untuk mengerahkan indera sebanyak mungkin kepada suatu objek sehingga mempermudah persepsi.

Ada beberapa hasil penelitian yang relevan dengan penelitian yang dilaksanakan. Hasil penelitian ini dapat digunakan untuk pengembangan terhadap penelitian yang diilaksanakan.

Penelitian Naima (2009) tentang pengaruh penggunaan media konkrit dan gambar serta motivasi terhadap hasil belajar siswa kelas V Madrasah Itbidiyah di Kota 
Pali. Penelitian dilakukan dengan membagi siswa menjadi kelompok, yakni kelompok eksperimen dan kelompok kontrol. Kelompok eksperimen menggunakan media konkrit dan gambar pada kegiatan belarjarnya, sedangkan kelompok kontrol hanya menggunakan metode ceramah pada kegiatan belajarnya. Hasil penelitian menunjukan bahwa ada pengaruh positif terhadap siswa yang menggunakan media konkrit dan gambar terhadap motivasi dan hasil belajar bila dibandingkan dengan kelompok yang tanpa menggunakan media konkrit.

\section{METODOLOGI PENELITIAN}

Penelitian ini dilaksanakan di SMK Negeri 1 Lubuk Pakam pada siswa Kelas XI Program keahlianTeknik Instalasi Tenaga Listrik. Pada semester genap (II) bulan Januari Tahun Pengajaran 2013/2014. Jenis penelitian yang dilaksanakan adalah penelitian eksperimen.

Populasi adalah keseluruhan siswa yang dijadikan sebagai objek penelitian, yaitu seluruh siswa kelas XI jurusan Teknik Instalasi Tenaga Listrik (TITL) SMK Negeri 1 Lubuk pakam T.A 2013/2014. Sementara untuk sampelnya ada 2 kelas ,yaitu XI-L $\mathrm{L}_{1}$ dan XI- $\mathrm{L}_{2}$ jumlah 68 orang

Teknik pengambilan sampel menggunakan teknik Vrovosive random sampling (Populasi Homogent), yaitu pengambilan sampel dilakukan secara acak tanpa memperhatikan strata yang ada. Dalam pengambilan sampel penelitian, pengambilan sampel juga tergolong dalam penggunaan metode pengambilan sampel insidental.

Sampel yang diambil dalam penelitian ini dibagi atas dua kelas yaitu kelas eksperimen dan kelas kontrol. Untuk kelas eksperimen diberikan metode pembelajaran Demonstrasi, sedangkan untuk kelas kontrol diberikan metode pembelajaran dengan pendekatan ekspositori. Jenis desain penelitian ini adalah desain yang menggunakan postest, dengan tabel 1 sebagai berikut.
Tabel 1. Desain Penelitian

\begin{tabular}{|c|c|c|}
\hline Kelas & Perlakuan & Postest \\
\hline Demonstrasi & $\mathrm{XI}_{1}$ & $\mathrm{P}_{1}$ \\
\hline Ekspositori & $\mathrm{XI}_{2}$ & $\mathrm{P}_{1}$ \\
\hline
\end{tabular}

Pengujian hipótesis dilakukan dengan cara Uji kesamaan rata-rata postest (uji t satu pihak). Uji t satu pihak digunakan untuk mengetahui adanya peningkatan hasil belajar MSPEM siswa dilihat dari ada tidaknya perbedaan hasil post tes siswa pada kedua kelas yaitu kelas eksperimen dan kelas kontrol. Pengujian ada tidaknya perbedaan hasil post tes siswa digunakan uji t satu pihak (pihak kanan).

\section{HASIL DAN PEMBAHASAN}

Penelitian dilakukan di SMK Negeri1 Lubuk Pakam tahun pengajaran 2014/2015 pada kelas XI mata pelajaran Mengoperasikan Sistem Pengendali Elektromagnetik (MSPEM), dengan tujuan untuk mengetahui perbandingan hasil belajar Mengoperasikan Sistem Pengendali Elektromagnetik (MSPEM) pada siswa yang diajar dengan Metode Demonstrasi dan siswa yang diajar dengan Metode Ekspositori dikelas XI SMK Negeri 1 Lubuk Pakam.

Setelah perlakuan diberikan kepada kedua kelas maka kedua kelas akan diberikan post test. Dari data post test yang telah diperoleh maka didapat pada kelas eksperimen diperolah rata-rata sebesar 78,8 dengan standart deviasi sebesar 10,2, untuk kelas kontrol diperoleh rata-rata sebesar 69,09 dengan standart deviasi sebesar 10,7 .

Hasil pengujian hipotesis untuk melihat apakah ada perbandingan hasil belajar Mengoperasikan Sisitem Pengendali Elektromagnetik (MSPEM) pada siswa yang diajarkan dengan metode demonstrasi dan siswa yang diajarkan dengan metode ekspositori dilakukan uji - $\mathrm{t}$ yang diperoleh dari rata-rata post test kelas eksperimen dan kelas kontrol diperoleh harga $t_{\text {hitung }}>t_{\text {tabel }}$ yaitu : 2,051>1,671 sehingga $\mathrm{H}_{\mathrm{a}}$ diterima dan $\mathrm{H}_{\mathrm{o}}$ ditolak pada taraf $\alpha=0,05$ dan dk 66, yang berarti ada perbedaan antara hasil belajar siswa yang diajar dengan menggunakan metode demonstrasi dan siswa 
yang diajar dengan menggunakan metode ekspositori pada siswa kelas XI SMK Negeri 1 Lubuk Pakam.

Pembelajaran dengan menggunakan metode demonstrasi dapat merangsang peserta didik untuk lebih memahami prinsip kerja dari komponen-komponen MSPEM ataupun peserta didik bisah tahu secara langsung bentuk dan prinsip kerja dari tiap-tiap komponen didasari dari kerucut pengalaman edgar edale semakin konkrit suatu pembelajaran yang dilakukan oleh guru, maka semakin besar pula pemahaman siswa dalam penerimaan materi yang akan disampaikan oleh guru.

\section{KESIMPULAN}

Berdasarkan hasil analisis dan pembahasan maka dapat disimpulkan bahwa: (1) Ada perbedaan hasil belajar siswa pada metode demonstrasi dan metode ekspositori, dan (2) Hasil belajar siswa yang menggunakan metode demonstrasi lebih tinggi dangan hasil belajar siswa yang menggunakan metode ekspositori.

Penggunaan media pembelajaran yang tepat akan menciptakan suasana belajar yang lebih baik demi tercapainya hasil belajar yang baik pula. Oleh karena itu, pemilihan media pembelajaran menjadi factor yang sangat penting dalam merencanakan kegiatan pembelajaran. Kegiatan pembelajaran dengan menggunakan metode ekspositori yang sering dilakukan oleh guru elektronika di SMK Negeri1 Lubuk Pakam, tidak harus sepenuhnya dilakukan karena hanya akan berdampak terhadap suasana belajar yang membentuk siswa menjadi pasif dan mudah bosan, dikarenakan penggunaan metode ekspositori yang aktif adalah guru sendiri. Ada baiknya jika penggunaan metode ekspositori juga didampingi oleh mediamedia yang mendukung proses belajar mengajar sehingga hasil belajar siswa lebih baik, seperti penggunaan media alat peraga.

Penerapan pembelajaran dengan menggunakan media demonstrasi menjadi salah satu bukti bahwa pembelajaran juga menuntuk keaktifan siswa untuk mengembangkan potensi dirinya sendiri sehingga hasil belajar yang didapat akan lebih optimal dan siswa lebih bersemangat dalam belajar. Dengan pembelajaran ini, siswa juga dapat dengan mudah memahami pembelajaran didalam bidang praktik.

\section{DAFTAR PUSTAKA}

Ananda Ricki 2013 "Perbandingan Hasil Belajar Elektronika Pada Siswa Yang

Diajar dengan Media Alat Peraga dan Siswa yang Diajarkan dengan Animasi Power Point Serta Siswa yang Diajarkan dengan Metode Pembelajaran Ekspositori di kelas X SMK Negeri 4 Tanjung Balai Tahun Pengajaran 2013/2014".Skripsi, Medan:Unimed.

Estiningsih. 1994. Pentingnya Penggunaan Alat Peraga dalam Pembelajaran. Dalam (http//: pentingnyapenggunaan-alat-peraga-dalam.html)

Hutasoit, P. 2005, "Perbedaan Hasil Belajar Antara Siswa Yang Diajar Dengan Strategi Variasi Pembelajaran Dengan Siswa Yang Diajar Dengan Strategi Membimbing Diskusi Kelompok Kecil Pada Mata Pelajaran PKDLE Siswa Kelas 1 SMK Negeri 1 Percut Sei Tuan Tahun Ajaran 2004/2005". Skripsi, Medan:Unimed.

Jarolimek, Foster 1977, Strategi Pembelajaran, New York, MacMillan Publishing Co. Inc

Martinis Yamin 2008, Pengertian Demonstrasi, Jakarta, MEDIA PERSADA

Nailma.2009."Meningkatkan Hasil Belajar Siswa Melalui Penggunaan Alat Peraga Digital Dasar Pada Pembelajaran Menerapkan DasarDasar Teknik Digital Di Smk Swasta HKBP Pematang Siantar. Skripsi. Medan:Unimed.

Purba, Edward, dkk. 2004, Belajar dan Pembelajaran, Medan:Unimed

Roestiyah NK, 2001, Srategi Belajar Mengajar, Jakarta, Rineka Cipta

Romiszowski. 2012. Media dan Alat Peraga Dalam Pembelajaran Mate-matika. (Online).Dalam (http//:sharingposting.blogspot.com) 
Syaiful Bahri Djamrah.2000. "Perbedaan Strategi Pembelajaran Kooperatiftipe student teams achievement division (STAD) dengan ekspositori terhadap hasil belajar menguasai dasar dasar elektronika pada siswa kelas $\mathrm{x}$ program keahlian audio video smk swasta teladan sumut 2 medan t.a 20011/2012”. Skripsi.Medan:Unimed

Sanjaya, Wina 2008. Strategi Pembelajaran. Jakarta: Kencana Prenada Media Grup

Syah, M., 2003, Psikologi Pendidikan Dengan Pendekatan Baru, Bandung: Remaja Rosdakarya
Slameto, 2003, Belajar dan Faktor-faktor Yang Mempengaruhinya, Jakarta: RinekaCipta.

Sudjana, 1992, Metode Statistik, Bandung:Tarsito. 2005, Metode Statistik, Bandung:Tarsito.

Winkel, W. S 1996 Psikologi Belajar Pengajaran, Jakarta:Grameda 